\title{
Analyse archéologique de la céramique : un cas de la région du Dhar Tichitt (Mauritanie)
}

\section{Augustin Holl}

\section{(2) OpenEdition}

\section{Journals}

Édition électronique

URL : https://journals.openedition.org/tc/957

DOI : $10.4000 /$ tc. 957

ISSN : 1952-420X

Éditeur

Éditions de l'EHESS

\section{Édition imprimée}

Date de publication : 1 juin 1985

ISSN : 0248-6016

\section{Référence électronique}

Augustin Holl, « Analyse archéologique de la céramique : un cas de la région du Dhar Tichitt (Mauritanie) 》, Techniques \& Culture [En ligne], 5 | 1985, mis en ligne le 25 janvier 2006, consulté le 29 septembre 2022. URL : http://journals.openedition.org/tc/957 ; DOI : https://doi.org/10.4000/tc.957

Ce document a été généré automatiquement le 29 septembre 2022.

Tous droits réservés 


\section{Analyse archéologique de la céramique : un cas de la région du Dhar Tichitt (Mauritanie)}

Augustin Holl 